\title{
Estrogen receptors alpha and beta in rat placenta: detection by RT-PCR, real time PCR and Western blotting Maie D Al-Bader*
}

\author{
Address: Department of Physiology, Faculty of Medicine, Kuwait University, P.O. Box 24923, Safat, Zip Code 13110, Kuwait \\ Email: Maie D Al-Bader* - albader@hsc.edu.kw \\ * Corresponding author
}

Published: 28 March 2006

Reproductive Biology and Endocrinology2006, 4:13 doi:10.1186/1477-7827-4-13

This article is available from: http://www.rbej.com/content/4/I/I3

(c) 2006Al-Bader; licensee BioMed Central Ltd.

This is an Open Access article distributed under the terms of the Creative Commons Attribution License (http://creativecommons.org/licenses/by/2.0), which permits unrestricted use, distribution, and reproduction in any medium, provided the original work is properly cited.
Received: 05 February 2006

Accepted: 28 March 2006

\begin{abstract}
Background: High levels of estrogens during pregnancy not only retard placental and fetal growth but can lead to reproductive tract abnormalities in male progeny. Estrogens act through estrogen receptors (ER) to modulate the transcription of target genes. These ER exist in two isoforms, ER alpha and ER beta and recently several variants of these isoforms have been identified.
\end{abstract}

Methods: The expressions of ER isoforms and variants have been studied in rat placenta at 16, 19 and $2 \mathrm{I}$ days gestation $(\mathrm{dg})$. Gene expression was assessed using RT-PCR and real time PCR while protein expression was studied using Western blotting followed by immunodetection. Placental homogenates were probed with: a monoclonal antibody raised against the steroid binding domain of the ER alpha (ER alpha $-S$ ), a monoclonal antibody raised against the hinge region of ER alpha (ER alpha $-\mathrm{H}$ ) and a polyclonal antibody raised against the amino terminus of ER beta.

Results: ER alpha and ER beta mRNA and protein were detected from as early as $16 \mathrm{dg}$. Two PCR products were detected for ER alpha, one for the wild type ER alpha, and a smaller variant. Real time PCR results suggested the presence of a single product for ER beta. The antibodies used for detection of ER alpha protein both identified a single $67 \mathrm{kDa}$ isoform; however a second $54 \mathrm{kDa}$ band, which may be an ER alpha variant, was identified when using the ER alpha $-\mathrm{H}$ antibody. The abundance of both ER alpha bands decreased significantly between 16 and $19 \mathrm{dg}$. As for ER beta, four bands $(76,59,54$ and $4 \mathrm{l} \mathrm{kDa})$ were detected. The abundance of the 59 and $54 \mathrm{kDa}$ bands decreased significantly between 16 and $19 \mathrm{dg}$.

Conclusion: This study shows that both ER protein isoforms and their variants are present in rat placenta. The decrease in their expression near parturition suggests that the placenta may be relatively unresponsive to estrogens at this stage.

\section{Background}

Placental growth and function are of biological significance in that placental tissue promotes prenatal life and pregnancy maintenance. In many mammalian species the placenta produces estrogens during pregnancy suggesting a role for placental estrogens as paracrine factors in the regulation of placental growth and differentiation [1]. However, in contrast to the human placenta, which plays a role in producing progesterone and estrogen, the rat placenta does not produce estrogen [2,3] and secretes only small amounts of progesterone [4]. Indeed the rat placenta is the principal source of testosterone in the periph- 
eral circulation between days 14-18 of pregnancy [5] and this testosterone serves as the substrate for estradiol synthesis in the corpus luteum [6]. Thus although the rat placenta does not produce estradiol it sustains the ovarian production of this hormone.

Estrogen and progesterone are both essential for the initiation and maintenance of pregnancy in the rat. With regard to progesterone, growth and development of the embryo and fetus are unaffected over a wide range of progesterone concentrations in maternal plasma [7]. On the other hand, pharmacological doses of estrogens cause high levels of embryonic mortality [8], although administration later in pregnancy causes retarded fetal growth with less effect on survival [9].

In order for estrogens to exert their biological effects, they need to bind to the ER which then undergoes a conformational change allowing it to interact with chromatin and to modulate transcription of target genes [10]. ER exists in two different isoforms, ER alpha and ER beta (ER $\alpha$ and ER $\beta$ ) [11-13]. Both proteins are physiologically relevant, they bind estradiol with high affinity and activate transcription of estrogen responsive reporter gene constructs expressed in mammalian cell lines $[11,14]$.

There is increasing concern over the known effects of various chemicals released into the environment on the reproduction of humans and other species. It is well known that gonadal steroids function as organizational agents during fetal development and thus exposure of the developing fetus to exogenous estrogens can cause long term deleterious effects. This led to the assumption that a possible cause for the rise in male reproductive tract abnormalities may be the inappropriate exposure to estrogens or suspected environmental estrogenic chemicals during fetal and/or neonatal life $[15,16]$. The estrogenic potency of industrial-derived estrogenic chemicals is limited but the estrogenic potency of phytoestrogens is significant, especially for ER $\beta$ and may trigger many of the biological responses that are induced by the physiological estrogens [17].

The present study was therefore designed to: 1) investigate whether ER proteins are present in rat placentae and 2) to test the hypothesis of whether maternal estrogens act as local regulatory factors on ER mRNA and protein expression. Accordingly, estrogen receptor alpha and beta mRNA and protein expression was studied in rat placentae at different days gestation. In this article we have demonstrated that both ER isoforms (ER $\alpha$ and ER $\beta$ ) are expressed in rat placentae as early as $16 \mathrm{dg}$ and that these isoforms and some of their variants (term used in this article to refer to the subtypes of each isoform) tend to decrease with progression of pregnancy probably due to the high levels of sex steroids towards term.

\section{Materials and methods \\ Materials}

The polyclonal antibody corresponding to amino acids 1150 of the ER $\beta$ was purchased from Santa Cruz Biotechnology, Inc., U.S.A (catalogue \# H-150; sc-8974). Two monoclonal antibodies raised against different epitopes of the ER $\alpha$ were used: one raised against the steroid binding domain of the ER $\alpha$ (amino acid residues 495-595; referred to as ER $\alpha-S$; catalogue \# C-311; Santa Cruz Biotechnology, Inc., U.S.A) and the other raised against the hinge region (amino acid residues 287-300; referred to as ER $\alpha-\mathrm{H}$; catalogue \# SRA-1000; Stressgen Biotechnologies Corp., Canada). The actin monoclonal antibody was purchased from Santa Cruz Biotechnology, Inc., U.S.A (catalogue \# C-2). PVDF membranes were obtained from Amersham Pharmacia Biotech Ltd., U.K.

\section{Animals}

Sprague-Dawley rats were obtained from Bantin and Kingman (U.K.). The rats were housed in the Animal Resources Centre at the Faculty of Medicine, Kuwait University and had free access to food and water. The rats were maintained on a cycle of $12 \mathrm{~h}$ light and $12 \mathrm{~h}$ darkness at $22^{\circ} \mathrm{C}$. The experiments were carried out in accordance with the rules of laboratory animal care in this institution.

\section{Tissue collection}

Female rats were mated with males and mating was verified by the presence of sperm in the vaginal smear; this was designated as day 0 of pregnancy. Pregnant dams were stunned and killed by cervical dislocation at 16, 19 or 21 days gestation (dg). Uterine horns containing conceptuses were removed and placed immediately on ice. Fetuses and placentae were separated and placental tissues from each litter were pooled (four pregnancies were obtained at each gestational age $[n=4]$ and three to four placental tissues per pregnancy were pooled). The maternal uterus and maternal brain of the $21 \mathrm{dg}$ dams were used as a positive control (data not shown). The cryoprotective agent, dimethylsulfoxide, $(10 \% \mathrm{v} / \mathrm{v})$ was added before freezing at $-70^{\circ} \mathrm{C}$ for subsequent analysis.

\section{RNA isolation and quantification}

Samples were homogenized in denaturing solution (4 M guanidine thiocyanate salt, $25 \mathrm{mM}$ sodium citrate, $\mathrm{pH}$ 7.0, $0.5 \% \mathrm{w} / \mathrm{v}$ sarcosyl and $0.1 \mathrm{M}$ 2-mercaptoethanol) using a sterile hand-held homogenizer. To $3.6 \mathrm{ml}$ homogenate, $0.36 \mathrm{ml}$ sodium acetate $(2 \mathrm{M}, \mathrm{pH} 4.0), 3.6$ $\mathrm{ml}$ citrate buffer-saturated phenol $(\mathrm{pH} 4.3)$ and $0.72 \mathrm{ml}$ chloroform:isoamyl alcohol (49:1) were added sequentially, shaking well between each addition. Tubes were vigorously shaken for $15 \mathrm{~s}$ after the final addition. Tubes 
were kept on ice for $15 \mathrm{~min}$, then centrifuged $(10,000 \mathrm{~g}$ for $20 \mathrm{~min}$ at $4{ }^{\circ} \mathrm{C}$ ). The aqueous phase was removed, avoiding the DNA interphase, and an equal volume of icecold isopropanol was added. After shaking, tubes were kept at $-20^{\circ} \mathrm{C}$ for $>1 \mathrm{~h}$. The precipitate was collected by centrifugation $\left(10,000 \mathrm{~g}\right.$ for $20 \mathrm{~min}$ at $\left.4^{\circ} \mathrm{C}\right)$ and dissolved in $0.3 \mathrm{ml}$ denaturing solution. Nucleic acid was re-precipitated by adding an equal volume of ice cold-isopropanol. After $>1 \mathrm{~h}$ at $-20^{\circ} \mathrm{C}$, the samples were centrifuged $(10,000$ $\mathrm{g}$ for $10 \mathrm{~min}$ at $4^{\circ} \mathrm{C}$ ). The pellet was washed twice with 1 $\mathrm{ml} 75 \%(\mathrm{v} / \mathrm{v})$ ethanol $\left(\mathrm{at}-20^{\circ} \mathrm{C}\right)$ by suspension/centrifugation. The final pellet was air-dried, then dissolved in $0.5 \%(\mathrm{w} / \mathrm{v}) \operatorname{SDS}(0.25 \mu \mathrm{l} / \mathrm{mg}$ wet weight tissue $)$ at $65^{\circ} \mathrm{C}$ for $15 \mathrm{~min}$. Extracted RNA was stored at $-70^{\circ} \mathrm{C}$. The quality and quantity of total RNA sample was determined using spectroscopic measurements at 260 and $280 \mathrm{~nm}$. Samples with $A_{260} / A_{280}$ ratios $>1.7$ were only studied further. The integrity of total RNA was checked by agarose gel electrophoresis and 28S and 18S rRNAs visualized after ethidium bromide staining.

\section{Reverse Transcription Polymerase Chain Reaction (RT- PCR)}

SDS was removed from total RNA by precipitation with sodium acetate-isopropanol then resuspended (at $c a .1$ $\mu \mathrm{g} / \mu \mathrm{l})$ in water. The RNA concentration was determined by spectrophotometery and was adjusted to $0.5 \mu \mathrm{g} / \mu \mathrm{l}$ with water. All samples were DNase treated before reverse transcription. Briefly, $2 \mu \mathrm{g}$ of total RNA was mixed on ice with $40 \mathrm{U}$ of RNasin, $1 \mathrm{U}$ of DNase and $1 \times$ DNase buffer in a final volume of $20 \mu \mathrm{l}$. The mixture was left at room temperature for $15 \mathrm{~min}$ and the reaction was terminated by adding $2 \mu \mathrm{l}$ of $25 \mathrm{mM}$ EDTA and heating at $70^{\circ} \mathrm{C}$ for 10 $\mathrm{min}$. The DNase-treated sample was divided into two 11 $\mu \mathrm{l}$ aliquots, $100 \mathrm{ng}$ random hexamers were added and the mixture was heated at $70^{\circ} \mathrm{C}$ for $10 \mathrm{~min}$, immediately chilled on ice for $>3$ min then briefly centrifuged. With the tube on ice, the following were added: $1 \times$ first strand buffer ( $25 \mathrm{mM}$ Tris-HCl pH 8.3, containing $37.5 \mathrm{mM} \mathrm{KCl}$ and $\left.1.5 \mathrm{mM} \mathrm{MgCl}_{2}\right), 5 \mathrm{mM}$ DTT and $500 \mu \mathrm{M} \mathrm{dNTP} \mathrm{mix.}$ To one tube (RT+ reaction) $200 \mathrm{U}$ Superscript II RNase $\mathrm{H}^{-}$ reverse transcriptase were added, whereas water was added to the other tube (control RT-reaction) in a final volume of $20 \mu \mathrm{l}$. After gentle mixing, reactions were incubated at room temperature for $10 \mathrm{~min}$ then at $42^{\circ} \mathrm{C}$ for 50 min. Reactions were terminated by heating at $70^{\circ} \mathrm{C}$ for 15 $\min$.

The PCR reaction was carried out in a programmable thermal cycler (Perkin Elmer, model 9700). The ER $\alpha$ primer sets used were rER $\alpha$ U (5'-TAAGAACCGGAGGAAGAGTTG) and rER $\alpha$ L (5'-TCATGCGGAATCGACTTG) that give an expected 623 bp product. The $18 \mathrm{~S}$ housekeeping gene primer sets $\mathrm{r} 18 \mathrm{~S}$ U (5'-GTCCCCCAACTTCTTAGAG) and r18S L (5'-CACCTACGGAAACCTTGTTAC) give an expected 419 bp product. The reaction mixture consisted of: $1 \times$ PCR buffer ( $20 \mathrm{mM}$ Tris $/ 50 \mathrm{mM} \mathrm{KCl}), 3 \mathrm{mM}$ $\mathrm{MgCl}_{2}, 0.5 \mathrm{mM}$ dNTPs and $0.3 \mu \mathrm{M}$ each of upper and lower primers, $0.5 \mu \mathrm{l}$ template ( $\mathrm{RT}^{+}$, or RT- in addition to a water sample used as a negative control) and $1.25 \mathrm{U}$ recombinant Taq DNA polymerase in a final volume of 25 $\mu \mathrm{l}$. The PCR reactions were then cycled as follows: $5 \mathrm{~min}$ at $94^{\circ} \mathrm{C}$ ( 1 cycle); $30 \mathrm{~s}$ at $94^{\circ} \mathrm{C}$ (denaturation step), $30 \mathrm{~s}$ at the $45^{\circ} \mathrm{C}$ (annealing step) and $1 \mathrm{~min}$ at $72^{\circ} \mathrm{C}$ (extension step) for the required number of cycles (24 cycles for $18 \mathrm{~S}$ and 32 cycles for $E R \alpha$ ). Tubes were then incubated for a further $7 \mathrm{~min}$ at $72^{\circ} \mathrm{C}(1 \mathrm{cycle})$.

\section{Real Time PCR (ReT-PCR)}

The ReT-PCR reaction was carried out in a ReT-PCR system (Applied Biosystems, model 7500). The endogenous control, $\beta$-glucuronidase, used in this experiment was supplied by Applied Biosystems. The ER $\beta$ primer sets used detect both the wild type and a variant that has a $54 \mathrm{bp}$ (18aa) in-frame sequence between exons 5 and 6 of wild type ER $\beta$ [18]. These primer sets were rER $\beta$ LBD U (5'GAGCTCAGCCTGTTGGACC) and rER $\beta$ LBD L (5'GGCCTTCACACAGAGATACTCC) [19]. The PCR reactions were prepared using the Taq Man universal master mix (\# 4324018, Applied Biosystems) then cycled as follows: $2 \mathrm{~min}$ at $50^{\circ} \mathrm{C}\left(1\right.$ cycle); $10 \mathrm{~min}$ at $95^{\circ} \mathrm{C}(1$ cycle $)$, $15 \mathrm{~s}$ at $95^{\circ} \mathrm{C}$ and $1 \mathrm{~min}$ at $60^{\circ} \mathrm{C}$ for 60 cycles.

\section{Isolation of proteins and western blot analysis}

Placentae were thawed and washed twice with ice-cold isotonic saline then homogenized in ice-cold homogenization buffer containing glycerol [to stabilize the receptors] and protease inhibitors (10 mM Tris- $\mathrm{HCl} \mathrm{pH} \mathrm{7.4,} 1.5$ $\mathrm{mM}$ EDTA and $10 \% \mathrm{v} / \mathrm{v}$ glycerol, $1.0 \mathrm{mM}$ DTT, $1 \mu \mathrm{g} / \mathrm{ml}$ leupeptin, $100 \mu \mathrm{g} / \mathrm{ml}$ bacitracin, $2 \mu \mathrm{g} / \mathrm{ml}$ aprotonin, $1 \mu \mathrm{g} /$ $\mathrm{ml}$ pepstatin A), using a Polytron homogenizer, to yield a $5 \%(\mathrm{w} / \mathrm{v})$ homogenate (the total receptor fraction). Homogenates were passed through a nylon mesh (110 $\mu \mathrm{m}$ pore size) then through steel gauze ( $40 \mu \mathrm{m}$ pore size). An aliquot was removed for protein assay. Samples (50$100 \mu \mathrm{g}$ protein) and molecular weight rainbow markers $(14,300$ - 220,000 daltons; Amersham Pharmacia Biotech Ltd., U.K.) were mixed with loading buffer $(0.03 \% \mathrm{w} /$ $\mathrm{v}$ bromophenol blue, $32 \mathrm{mM}$ Tris-HCl pH $6.8,8 \% \mathrm{w} / \mathrm{v}$ dithiothreitol and $4 \% \mathrm{w} / \mathrm{v}$ SDS), boiled for $5 \mathrm{~min}$, then chilled on ice and centrifuged $(10,000 \times \mathrm{g}$ for $1 \mathrm{~min})$. Samples were then electrophoresed (SDS PAGE; 7.5\% polyacrylamide gels). The distance migrated by the marker proteins and bromophenol blue front were measured. The buffer chamber of the electrophoresis apparatus was filled with degassed transfer buffer $(25 \mathrm{mM}$ Tris-HCl, $150 \mathrm{mM}$ glycine, $20 \% \mathrm{v} / \mathrm{v}$ methanol and $0.1 \% \mathrm{w} / \mathrm{v}$ SDS, $\mathrm{pH}$ 8.3). Gels were equilibrated in transfer buffer then protein was transferred to PVDF membranes with a con- 
Table I: Litter size, feto-placental growth and placental protein measurements.

\begin{tabular}{cccccc}
\hline Days gestation (dg) & Litter number & Placentae weights (g) & Fetal body weights (g) & $\begin{array}{c}\text { Protein } \\
\text { concentration } \\
\text { (mg/g wet wt) }\end{array}$ & $\begin{array}{c}\text { Protein content } \\
\text { (mg/tissue) }\end{array}$ \\
\hline 16 & $12 \pm 1$ & $0.313 \pm 0.010$ & $0.513 \pm 0.016$ & $90.904 \pm 3.559$ & $28.489 \pm 1.893$ \\
19 & $11 \pm 1$ & $0.508 \pm 0.012^{*}$ & $2.371 \pm 0.060^{*}$ & $98.004 \pm 3.476$ & $49.709 \pm 1.014^{*}$ \\
21 & $9 \pm I^{*}$ & $0.546 \pm 0.007^{*}$ & $5.387 \pm 0.166^{*}$ & $95.307 \pm 3.713$ & $52.053 \pm 2.037^{*}$ \\
\hline
\end{tabular}

Values are mean \pm S.E.M. for four different dams. A significant increase $(p<0.00 I)$ in placental and fetal body weights during gestation and a significant decrease $(p<0.001)$ in litter number between 16 and $21 \mathrm{dg}$ was detected. Placental protein concentration was measured using the Bradford method; a significant increase in protein content was observed between 16 and $19 \mathrm{dg}$ and 16 and $21 \mathrm{dg}$ (*p < $0.00 \mathrm{I}$; LSD test).

stant current of $300 \mathrm{~mA}$ overnight with cooling. After transfer the membranes were dried and stored at $4^{\circ} \mathrm{C}$.

\section{Immunodetection}

Membranes were blocked for $1 \mathrm{~h}$ at room temperature with $10 \%$ non-fat dry milk in TBS-T (20 mM Tris, $137 \mathrm{mM}$ $\mathrm{NaCl}, \mathrm{pH} 7.6$ and $0.1 \% \mathrm{v} / \mathrm{v}$ Tween). The membranes were washed by rinsing twice with TBS-T, followed by two 10 min washes $(20 \mathrm{ml} /$ wash $)$. Membranes were then incubated overnight at $4^{\circ} \mathrm{C}$ with $3 \mathrm{ml}$ primary antibody solution diluted in 5\% w/v non-fat dry milk in TBS-T (ER $\alpha-S$ diluted 1:500, ER $\alpha-\mathrm{H}$ diluted 1:1000 and ER $\beta$ antibody diluted 1:1000). After incubation, the membranes were rinsed twice with TBS-T followed by one $15 \mathrm{~min}$ wash and two $5 \mathrm{~min}$ washes $(20 \mathrm{ml} /$ wash $)$. Membranes were incubated with the appropriate secondary antibody (antimouse Ig HRP linked diluted 1:20000 or anti-rabbit Ig HRP linked diluted 1:10000 in TBS-T) for $1.5 \mathrm{~h}$ at room temperature then rinsed twice with TBS-T followed by one $15 \mathrm{~min}$ wash and four $5 \mathrm{~min}$ washes (20 ml/wash). Detection was by chemiluminescence after incubation with an HRP-linked secondary antibody - using a commercial kit (ECL-Plus; Amersham Pharmacia Biotech Ltd., U.K.) and standard methodology. After obtaining the results for the respective estrogen receptor primary antibodies, the membranes were stripped in stripping buffer (100 mM 2-mercaptoethanol, 2\% SDS, $62.5 \mathrm{mM}$ Tris-HCl pH 6.7) at $50^{\circ} \mathrm{C}$ for $30 \mathrm{~min}$ with occasional shaking. The membranes were then washed twice in TBS-T for 10 minutes each before being re-probed with anti-actin antibody (diluted 1:500 in TBS-T) which served as an internal control. All results were expressed relative to actin.

\section{Protein determination}

Protein was determined by a dye-binding method using Coomassie Plus Protein assay reagent (Pierce \& Wariner Ltd, U.K.)

\section{Determination of protein sizes}

In order to determine the sizes of the bands a marker lane was always included. The distance migrated by the protein marker was measured and a standard curve constructed using a plot of $\log _{10}$ molecular mass versus relative mobil- ity (distance migrated by band $\div$ distance migrated by dye; $\mathrm{R}_{\mathrm{f}}$ ). The size of the unknown protein band was then determined using the equation of the line.

\section{Data analysis}

After the RT-PCR reaction for ER $\alpha$, PCR products were electrophoresed alongside a $100 \mathrm{bp}$ DNA marker (100 bp ladder, Gibco), through a $2 \%$ (w/v) low electroendosmosis (LE; Boehinger Manheim) agarose gel stained with ethidium bromide. All images were captured using Gene Genius Bio Imaging System and od values of PCR products were measured using Gene Tools Software. As for ReT-PCR the results for the average CT threshold cycle for each sample was used to express the relative expression of $\operatorname{ER} \beta$ to $\beta$-glucuronidase.

Statistical analysis was performed using SPSS (ANOVA followed by post-hoc analysis [LSD]) when the test for homogeneity of variance was fulfilled and using GamesHowell post-hoc analysis when the homogeneity of variances was not attained. All data shown are mean \pm S.E.M. and a value of $<0.05$ was taken as the minimum level of significance.

\section{Results \\ Gross parameters}

As expected there was a significant increase $(\mathrm{p}<0.001)$ in placental weights and fetal body weights with gestation (Table 1). As for the litter number, there was a significant decrease ( $\mathrm{p}<0.001$ ) between 16 and $21 \mathrm{dg}$ and fetal resorptions were detected in some dams, however, these dams were not included in this study.

\section{Protein concentration and content}

There was no significant change in placental protein concentration (Table 1), nevertheless, a significant increase in protein content was observed between 16 and $19 \mathrm{dg}$ ( $\mathrm{p}<$ $0.001)$. This increase was in parallel with the increase in placentae weight noticed with gestation (Table 1).

\section{Estrogen receptor alpha gene expression}

The expected PCR product (623 bp) for the ER $\alpha$ mRNA was detected in rat placentae from as early as $16 \mathrm{dg}$ (Figure 
A)

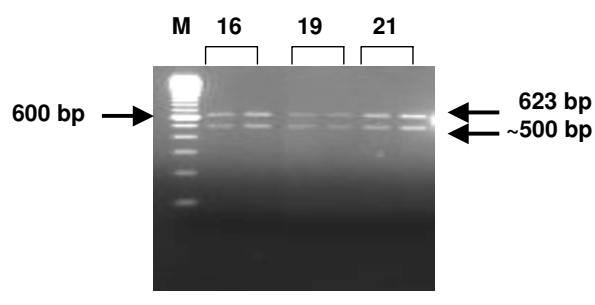

B)

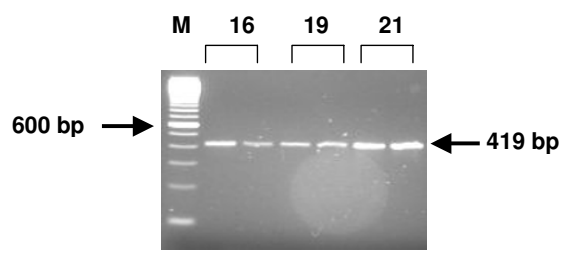

C)

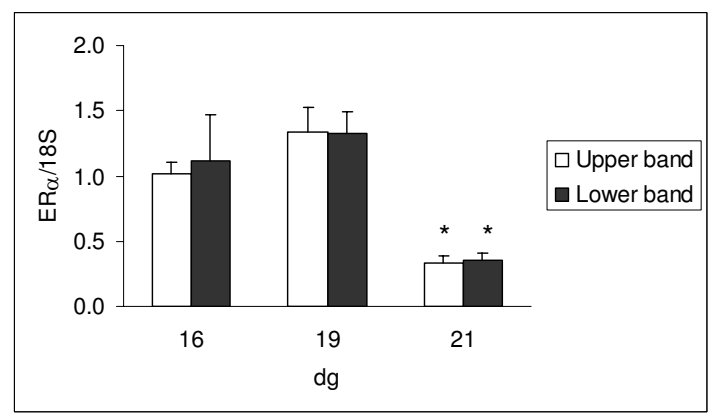

Figure I

Expression of ER $\alpha$ transcript in rat placentae during gestation. [A] Ethidium bromide stained gel for ER $\alpha$. The migration of the 100 bp marker $(M)$ is shown on the lefthand side and the calculated size of the signal indicated on the right-hand side of the gel (expected size is $623 \mathrm{bp}$ ). An extra $\sim 500$ bp band was detected for ER $\alpha$. Both RT- and water samples were negative (data not shown). Reactions were performed for 32 cycles at $45^{\circ} \mathrm{C}$, using standard reaction conditions. [B] Ethidium bromide stained gel for I8S. The migration of the 100 bp marker $(M)$ is shown on the lefthand side and the calculated size of the signal indicated on the right-hand side of the gel (expected size is $419 \mathrm{bp})$. Both RT- and water samples were negative (data not shown). Reactions were performed for 24 cycles at $45^{\circ} \mathrm{C}$, using standard reaction conditions. [C] Relative ER $\alpha$ mRNA level. The amount of product was expressed relative to I8S. Samples were run in duplicates; results shown are mean \pm S.E.M. $(n=4)$. A significant decrease in ER $\alpha$ mRNA expression was detected between 16 and $21 \mathrm{dg}$ and 19 and $21 \mathrm{dg}$ for both PCR products $\left(*_{p}<0.001\right)$.

1). However, a 500 bp product was also detected from 16 dg. The RT- and W reactions did not show any bands (figures not shown), indicating that the amplified products in
RT+ reactions are not due to genomic DNA nor due to contamination of reagents, respectively. The od measurements of PCR products obtained for ER $\alpha$ gene were expressed relative to the od obtained from 18S. When expressed relative to the $18 \mathrm{~S}$ housekeeping gene it was seen that the pattern of expression of both products relative to $18 \mathrm{~S}$ was similar with a significant decrease in ER $\alpha$ mRNA expression between 16 and $21 \mathrm{dg}$ and 19 and 21 $\operatorname{dg}\left({ }^{*} \mathrm{p}<0.001\right)$.

\section{Estrogen receptor beta gene expression}

Using RT-PCR it was not possible to detect ER $\beta$ mRNA expression. However, using ReT-PCR it was possible to amplify the ER $\beta$ gene (Figure 2). The average threshold cycle $\left(\mathrm{C}_{\mathrm{T}}\right)$ for duplicate samples was expressed relative to that of $\beta$-glucuronidase (endogenous or housekeeping gene). No significant change in ER $\beta$ gene expression was detected with gestation.

\section{Estrogen receptor alpha protein expression}

A 67 kDa single band for ER $\alpha$ was observed for the placental samples using both the ER $\alpha-\mathrm{H}$ and the ER $\alpha-\mathrm{S}$ antibodies from as early as $16 \mathrm{dg}$ (Figures $3 \& 4$, respectively). However, using the ER $\alpha-\mathrm{H}$ antibody, another band of apparent molecular weight of $54 \mathrm{kDa}$ was detected. The abundance of these ER $\alpha$ variants decreased significantly between 16 and $19 \mathrm{dg}(\mathrm{p}<0.05)$ as shown when the ER $\alpha$ $\mathrm{H}$ antibody was used. However, using the second antibody, ER $\alpha-S$, no apparent change in protein expression was observed although the level at $19 \mathrm{dg}$ appeared lower but did not reach significance. The $54 \mathrm{kDa}$ band observed with the ER $\alpha-\mathrm{H}$ antibody was more abundant at $16 \mathrm{dg}$ compared to the $67 \mathrm{kDa}$ (Figure 3). This difference in expression was normalized by $19 \mathrm{dg}$.

\section{Estrogen receptor beta protein expression}

When studying the expression of the second estrogen receptor isoform, $\mathrm{ER} \beta$, four bands were detected with apparent molecular weights of 76, 59, 54 and $41 \mathrm{kDa}$ (Figure 5). When comparing the level of expression of the ER $\beta$ protein as pregnancy progressed, it was found that there was a significant decrease in expression of the 59 and 54 $\mathrm{kDa}$ bands ( $\mathrm{p}<0.001$ ) between 16 and $19 \mathrm{dg}$. Moreover, the $76 \mathrm{kDa}$ band showed a tendency to decrease at $19 \mathrm{dg}$, however, this was not statistically significant. On the other hand, the $41 \mathrm{kDa}$ ER $\beta$ variant showed a different pattern of expression with a trend to increase between 16 and $19 \mathrm{dg}$ (not statistically significant).

\section{Discussion}

In this study dams were sacrificed at 16, 19 and $21 \mathrm{dg}$, the number of fetuses was determined, placentae were collected and ER status was verified both at the mRNA and protein levels. It was rather interesting to observe that as pregnancy advanced there was a reduction in litter size 
A)

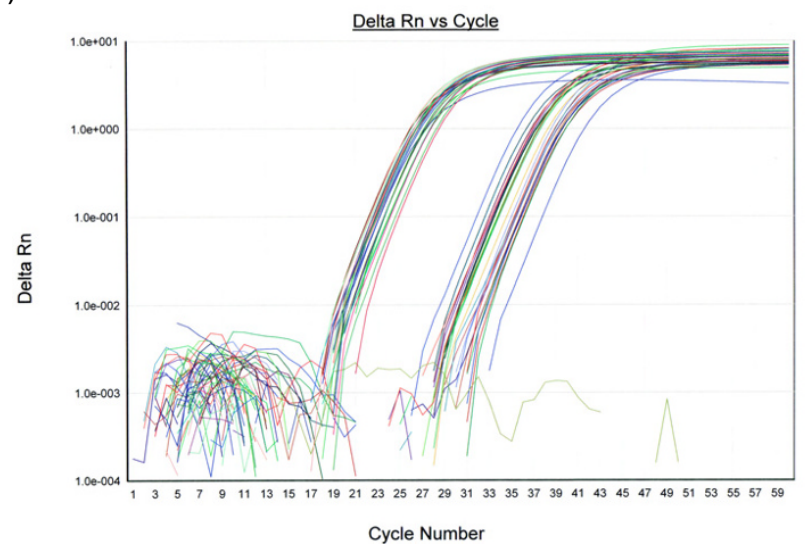

B)

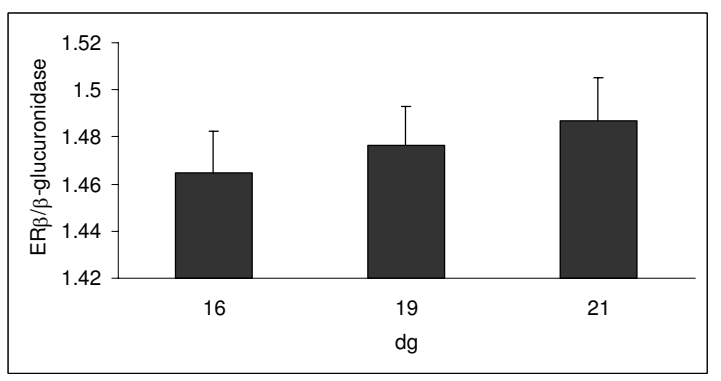

Figure 2

Expression of ER $\beta$ transcript in rat placentae during gestation. [A] ReT-PCR analysis for ER $\beta$ and $\beta$-glucuronidase. A graph showing delta Rn (change in normalized reporter expression) as a function of cycle number. Reactions were performed for 60 cycles at $60^{\circ} \mathrm{C}$, using recommended conditions by supplier. Samples were run in duplicates for both target and endogenous genes. [B] Relative ER $\beta$ gene expression. The average threshold cycle $\left(C_{T}\right)$ for duplicate samples was expressed relative to that of $\beta$-glucuronidase. Results shown are mean \pm S.E.M. $(n=4)$. No significant change in ER $\beta$ gene expression was detected.

number. This decrease has been explained by other investigators, studying various animal models, as being possibly due to fetal resorptions, a reduction in the number of maturing follicles, and/or atrophy of ovaries [20,21]. In our study fetal resorptions were observed in some pregnancies, however, when this was the case these animals were excluded from the study.

The differentiation and growth of the rat chorioallantoic placenta occurs between days 8 through 21 and the expression of ER was studied between 16 and $21 \mathrm{dg}$. However, before studying the expression of the ER isoforms in placental samples, the protein concentration was determined. Placental protein concentration showed no significant change with gestation, however, the increase in placental weight was accompanied by an increase in pro- tein content. This increase may have resulted from alterations in protein metabolism or cell gain.

It was clear when studying the expression of ER $\alpha$ and ER $\beta$ mRNA that there was a reduction in ER $\alpha$ mRNA by $21 \mathrm{dg}$; however, there was no change in ER $\beta$ mRNA expression with progression of pregnancy. A similar pattern for ER $\alpha$ and ER $\beta$ mRNA was reported in rat corpus luteum during pregnancy. The levels of ER $\alpha$ mRNA increased from early pregnancy, reached a maximum at mid-pregnancy and declined before parturition while levels of ER $\beta$ mRNA remained constant throughout pregnancy, with a significant decline at parturition [22]. Similarly a decline in ER $\alpha$ mRNA between days 11 and 16 of pregnancy was detected in rat decidua basalis [23].

To study whether the changes in gene expression reflect changes in protein, the expression of ER $\alpha$ and ER $\beta$ proteins were studied. For ER $\alpha$, two antibodies were used, one raised against the hinge region of the $\mathrm{ER} \alpha(\mathrm{ER} \alpha-\mathrm{H})$ and another against the steroid binding domain (ER $\alpha-S)$. It was found that when using the ER $\alpha-\mathrm{H}$ antibody, two bands of apparent molecular weights of 67 and $54 \mathrm{kDa}$ were detected, while when using the ER $\alpha$-S antibody only the $67 \mathrm{kDa}$ bands was identified. According to the suppliers, the ER $\alpha$-H antibody does not recognize the native ER in the inactive $8 \mathrm{~S}$ but reacts efficiently with the activated $4 \mathrm{~S}$ receptor and thus it may be that both the 67 and 54 $\mathrm{kDa}$ variants are activated forms of the ER $\alpha$ protein.

Although studies have shown the expression of ER $\beta$ messenger RNA (mRNA) in various tissues, the expression of this ER isoform has not been studied extensively at the protein level in placentae using Western blotting methodologies. In our study, four discrete bands were detected for ER $\beta$ with apparent molecular weights of 76, 59, 54 and 41 $\mathrm{kDa}$. The $59 \mathrm{kDa}$ band has been reported as the full length $\operatorname{ER} \beta$ [24-26] while the $54 \mathrm{kDa}[12,14]$ and the $41 \mathrm{kDa}$ bands, may be truncated variants of the ER $\beta$ isoform $[18,24,27]$. On the other hand, the higher molecular weight $76 \mathrm{kDa}$ protein band, may indicate that posttranslational modification, such as phosphorylation $[28,29]$ or glycosylation, $[30,31]$ of the ER $\beta$ protein has taken place.

The smaller molecular weight bands, which were seen when using the ER $\alpha-H$ and ER $\beta$ antibodies, could be variants caused by alternative splicing, ER degradation products or proteins that are not related to ER but cross-react with the antibody. The low molecular weight bands were not detected in maternal whole brain or maternal uterus homogenates (data not shown) indicating that they are tissue specific. As these truncated forms were also not seen in non-pregnant uterus [32], then they may result from mechanisms unique to uterine stroma during pregnancy. In mice it has been shown that estradiol induces protein- 
A)
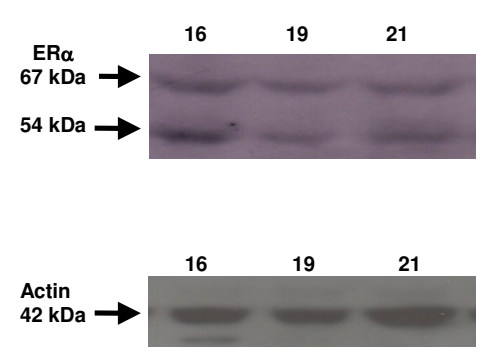

B)

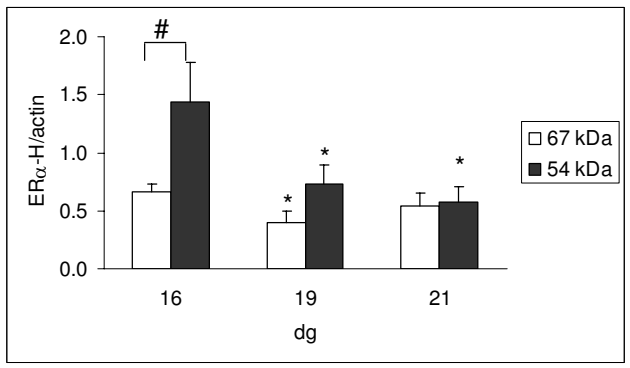

\section{Figure 3}

Protein expression using a monoclonal antibody $(E R \alpha-H)$ raised against the $E R \alpha$ hinge region. $100 \mu g$ of protein was loaded. [A] Representative Western blot for $E R \alpha$ and actin (which was used as an internal standard for normalizing the data); the calculated size of the band is indicated on the left-hand side of the gel. Two bands of apparent molecular weights of 67 and $54 \mathrm{kDa}$ were detected for $\mathrm{ER} \alpha$. [B] Ontogenic profile: ER $\alpha$ protein was expressed relative to actin. Results shown are mean \pm S.E.M. from four different dams; a significant decrease in $\mathrm{ER} \alpha$ protein expression was detected between 16 and $19 \mathrm{dg}$ for the $67 \mathrm{kDa}$ band $\left({ }^{*} \mathrm{p}<\right.$ $0.05)$. For the $54 \mathrm{kDa}$ band a significant decrease in ER $\alpha$ protein expression was detected between 16 and $19 \mathrm{dg}$ and 16 and $21 \mathrm{dg}\left({ }^{*} \mathrm{p}<0.05\right)$. The $54 \mathrm{kDa}$ band had a higher expression at $16 \mathrm{dg}$ when compared to the $67 \mathrm{kDa}$ band (\#p < 0.001 ; LSD test).

ase activities that degrade ER from a $65 \mathrm{kDa}$ molecule to a $54 \mathrm{kDa}$ variant [33]. Thus, the level of ER existing in target cells is dynamic and is probably under fine control by rapidly turning over proteinases, signifying an important posttranslational regulatory mechanism [32,33]. Posttranslational modification of ER could therefore be a common, albeit not appreciated, mechanism by which a target cell may regulate its responsiveness to estradiol.

There was a clear decline in ER $\alpha$ protein expression when the antibody that was raised against the hinge region was used. In fact the abundance of both the ER $\alpha$ variants (67 and $54 \mathrm{kDa}$ ) decreased significantly between 16 and 19 dg. Telleria et al. [22] has also shown that the antibody ER-
715 , raised against the hinge region of the rat, detected two bands 67 and $61 \mathrm{kDa}$; the $67 \mathrm{kDa}$ variant was highly expressed at mid-pregnancy but barely detectable in early and late gestation while the $61 \mathrm{kDa}$ variant remained unchanged. When using the antibody that was raised against the steroid binding domain, a significant decrease in the ER $\alpha$ protein expression was not detected, but there was a trend for the levels to decrease by $19 \mathrm{dg}$. The inability to reach significance may be due to the fact that this antibody is recognizing both the active and inactive receptors whereas the ER $\alpha-\mathrm{H}$ recognized only the activated receptor, which is down-regulated as shown by the decrease in levels between 16 and $19 \mathrm{dg}$. Thus, the results using the ER $\alpha-S$, which detects the total (inactive and active) receptor content, are influenced by the presence of the inactive receptor form which may not be down-regulated with gestation thereby biasing the overall result.

The decrease in abundance of the 59 and $54 \mathrm{kDa} \mathrm{ER} \beta$ variants between 16 and $19 \mathrm{dg}$ clearly indicate that there is down-regulation of the receptors. Although the $76 \mathrm{kDa}$ variant showed a tendency to decrease at $19 \mathrm{dg}$ this was not statistically significant. On the other hand, the $41 \mathrm{kDa}$ ER $\beta$ variant showed a different pattern of expression with a tendency to increase between 16 and $19 \mathrm{dg}$ but this also failed to reach statistical significance. The $41 \mathrm{kDa} E R \beta$ variant is probably derived from the native $59 \mathrm{kDa}$ moiety as it wasn't extensively expressed and yet became the dominant form as the levels of the native ER decreased and it may be one of many forms of degradation fragments that happened to contain the anti-ER $\beta$ epitope. These thus far unreported bands may be tissue specific and may have certain yet unidentified functions in the placenta.

It has been shown by several investigators that total estrogen concentrations in blood rise markedly during human [34-36] pregnancies. In addition, we have shown that estradiol levels rise during pregnancy from $33 \mathrm{pg} / \mathrm{ml}$ at 16 $\mathrm{dg}$ to $39 \mathrm{pg} / \mathrm{ml}$ at $21 \mathrm{dg}$ (unpublished data). The decrease in ER protein expression between 16 and $19 \mathrm{dg}$ may be due to down-regulation of the receptors by the high concentration of estradiol in pregnant dams towards the end of gestation [37,38] since down-regulation of hormone receptors by their ligands has been reported for steroid hormones [37,39]. This decrease in ER expression near parturition suggests that placentae are relatively unresponsive to estrogens at this stage, which agrees with studies shown by others on bovine [40] and human [41] placenta. In order for down-regulation to take place, high levels of estradiol concentrations $\geq 0.5 \mathrm{mg} / \mathrm{ml}$ are required [37]. It has been reported by Sheehan et al [42] that a 5.0 $\mathrm{mg} / \mathrm{ml}$ estradiol implant produces a steady serum estradiol level of $200 \mathrm{pg} / \mathrm{ml}$ and hence $0.5 \mathrm{mg} / \mathrm{ml}$, which would produce an equivalent of $20 \mathrm{pg} / \mathrm{ml}$ serum estradiol, will be sufficient to cause down-regulation of ER. 
A)

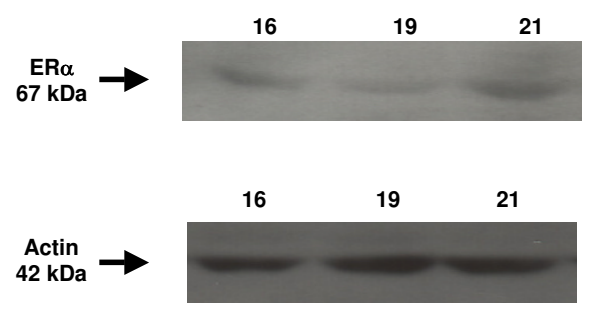

B)

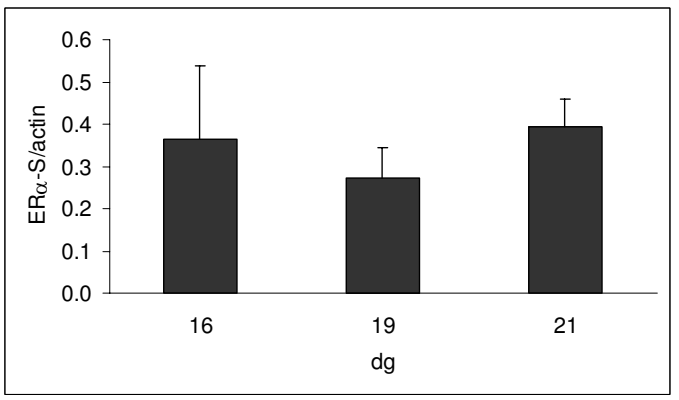

Figure 4

Protein expression using a monoclonal antibody $(E R \alpha-S)$ raised against the $E R \alpha$ steroid binding domain. $100 \mu \mathrm{g}$ of protein was loaded. [A] Representative Western blot for $\mathrm{ER} \alpha$ and actin (which was used as an internal standard for normalizing the data); the calculated size of the band is indicated on the left-hand side of the gel. [B] Ontogenic profile: ER $\alpha$ protein was expressed relative to actin. Results shown are mean \pm S.E.M. from four different dams; no significant change in protein expression was detected.

Progesterone decreases the quantity of uterine ER by interfering with the replenishment of cytoplasmic ER thus decreasing the sensitivity of the tissue to estrogen [43]. Reports have confirmed that progesterone lowers the levels of nuclear ER when given in the presence or absence of estradiol [39]. In a previous study, we have shown that at 16,19 and $21 \mathrm{dg}$ the levels of maternal serum estradiol were 33, 29 and $39 \mathrm{pg} / \mathrm{ml}$, respectively and levels in the amniotic fluid were 117, 157 and $226 \mathrm{pg} / \mathrm{ml}$, respectively [44]. Furthermore, levels of progesterone in maternal serum at 16,19 and $21 \mathrm{dg}$ were 107, 84 and $40 \mathrm{ng} / \mathrm{ml}$, respectively while in amniotic fluid the levels were 3, 3 and $4 \mathrm{pg} / \mathrm{ml}$, respectively [44]. Thus the high levels of estradiol and progesterone in both maternal serum and amniotic fluid would therefore be a contributing factor to the down-regulation of the estrogen receptors as pregnancy advanced.
A)

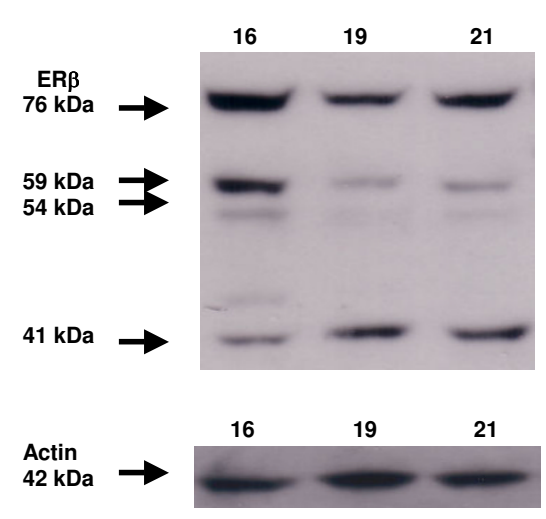

B)

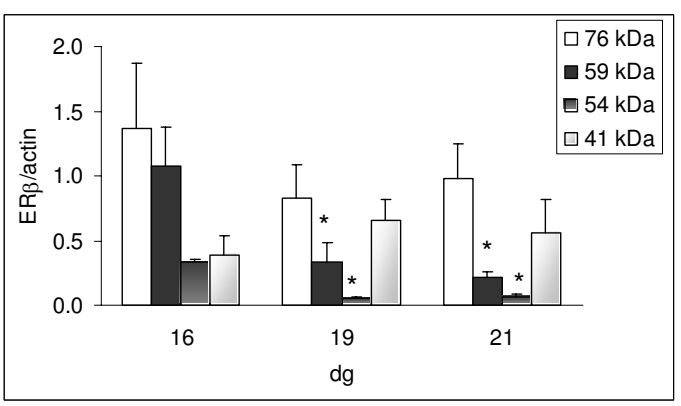

\section{Figure 5}

Protein expression using a polyclonal antibody $(E R \beta)$ raised against the $E R \beta$ amino terminal. $25 \mu \mathrm{g}$ of protein was loaded. [A] Representative Western blot for ER $\beta$ and actin (which was used as an internal standard for normalizing the data); the calculated size of the band is indicated on the left-hand side of the gel. Four bands of apparent molecular weight of 76, 59, 54 and 4I kDa were detected for ER $\beta$. [B] Ontogenic profile: ER $\beta$ protein was expressed relative to actin. Results shown are mean \pm S.E.M. from four different dams; a significant decrease in ER $\beta$ protein expression $(p<$ 0.001 ) was detected between 16 and $19 \mathrm{dg}$ and 16 and $21 \mathrm{dg}$ for both the 59 and the $54 \mathrm{kDa} \operatorname{ER} \beta$ bands (LSD test).

It is postulated that estradiol may have a specific growthretarding effect on the placenta $[45,46]$ that secondarily limits fetal growth $[47,48]$ and therefore, minor elevations of maternal estradiol can be fatal to the embryo. Inhibitory action of estradiol may relate to its ability to induce transforming growth factor mRNA [49] which in turn encodes a protein that promotes apoptosis in decidualized endometrial stromal cells [50]. Indeed, the identification of ER in rat placentae suggests that they are target cells of estrogens. However, the decrease in estrogen receptor protein expression with pregnancy suggests that the placenta becomes unresponsive to estrogens pointing towards a protective role played by the placenta to 1) minimize the growth retarding effects of estradiol and 2) min- 
imizing the possible deleterious effects of estrogens on the developing fetus. However, further studies on the function of ER proteins in placenta will provide a better understanding on their role during pregnancy.

\section{Conclusion}

In this study, both ER $\alpha$ and ER $\beta$ isoforms and variants were detected from $16 \mathrm{dg}$. The increase in sex steroid hormone levels, reported with progression of pregnancy, leads to down-regulation of the ER. This down-regulation serves as a protective mechanism from the possible deleterious effects that high estrogen levels could have on the developing fetus.

\section{Acknowledgements}

Financial support for this study was provided by the Kuwait University Grant No MY02/99. The author also acknowledges the skillful technical assistance of Dr. Sureikah S. Mohan, Mrs. Lizamma Jacob and Ms. Jocelin Jacob, with the collection and processing of samples.

\section{References}

I. Schuler G, Wirth C, Teichmann U, Failing K, Leiser R, Thole H, Hoffmann B: Occurrence of estrogen receptor $\alpha$ in Bovine placentomes throughout mid and late gestation and parturition. Biol Reprod 2002, 66:976-982.

2. Sybulski S: Testosterone metabolism by rat placenta. Steroids 1969, 14:427-440.

3. Townsend $\mathrm{L}$, Ryan $\mathrm{KJ}$ : In vitro metabolism of pregnenolone $17 \alpha^{3} \mathrm{H}$, progesterone-4-14 $\mathrm{C}$ and androstendione-4-14 $\mathrm{C}$ by rat placental tissue. Endocrinology 1970, 87:15I-I55.

4. Matt DW, Macdonald G]: In vitro progesterone and testosterone production by the rat placenta during pregnancy. Endocrinology 1984, II5:74I-747.

5. Sridaran R, Basurary R, Gibori G: Source and regulation of testosterone secretion in pregnant and pseudopregnant rats. Endocrinology 1981, 108:855-861.

6. Jackson JA, Albrecht ED: The development of placental androstendione and testosterone production and their utilization by the ovary for aromatization to estrogen during pregnancy. Biol Reprod 1985, 33:45 I-457.

7. Bartholomeusz RK, Bruce NW: Effects of maternal progesterone supplementation on fetal placental and corpus luteal weights in the rat. Biol Reprod 1976, 15:84-89.

8. Haddad V, Ketchel MM: Termination of pregnancy and occurrence of abnormalities following estrone administration during early pregnancy. Int J Fertil 1969, 14:56-63.

9. Kuhn ER, Bollen M, Darras $V$ : Fetal growth inhibition and decreased thyroid activity after injection of oestradiol benzoate into pregnant rats. J Endocrinol 1982, 93:55-63.

10. Tsai MJ, O'Malley BW: Molecular mechanisms of action of steroid/thyroid receptor superfamily members. Annu rev Biochem 1994, 63:45I-86.

II. Kuiper GG, Enmark E, Pelto-Huikko M, Nilsson S, Gustafsson JA: Cloning of a novel estrogen receptor expressed in rat prostate and ovary. Proc Natl Acad Sci USA 1996, 93:5925-5930.

12. Mosselman S, Polman J, Dijkema R: ER $\beta$ : identification and characterization of a novel human estrogen receptor. FEBS Lett 1996, 392:49-53.

13. Tremblay GB, Tremblay A, Copeland NG, Gilbert DJ, Jenkins NA, Labrie F, Giguere V: Cloning, chromosomal localization, \& functional analysis of the murine estrogen receptor $\beta$. Mol Endocrinol 1997, I I:353-365.

14. Kuiper GG, Carlsson B, Grandien K, Enmark E, Haggblad J, Nilsson S, Gustafsson JA: Comparison of the ligand binding specificity and transcript tissue distribution of estrogen receptors $\alpha$ and $\beta$. Endocrinology 1997, 138:863-870.

15. Sharpe RM, Skakkebaek NE: Are oestrogens involved in falling sperm counts and disorders of the male reproductive tract? Lancet 1993, 341:1392-1395.
16. Feldman D: Editorial: estrogens from plastic: are we being exposed? Endocrinology 1997, 138: 1777-1779.

17. Kuiper GGJM, Lemmen JG, Carlsson BO, Corton JC, Safe SH, van Der Saag PT, van der Berg B, Gustafsson J-A: Interaction of estrogenic chemicals and phytoestrogens with estrogen receptor $\beta$. Endocrinology 1998, 1 39:4252-4263.

18. Peterson DN, Tkalcevic GT, Koza-Taylor PH, Turi TG, Brown TA: Identification of estrogen receptor $\beta 2$, a functional variant of estrogen receptor $\beta$ expressed in normal rat tissues. Endocrinology 1998, 139:1082-1092.

19. Maruyama K, Endoh H, Sasaki-Iwaoka H, Kanou H, Shimaya E, Hashimoto $\mathrm{S}$, Kato $\mathrm{S}$, Kawashima $\mathrm{H}$ : A novel isoform of rat estrogen receptor beta with 18 amino acid insertion in the ligand binding domain as a putative dominant negative regular of estrogen action. Biochem Biophys Res Commun 1998, 246:142-147.

20. Parrott MW, Johnston ME, Durbin PW: The effects of thyroid and parathyroid deficiency on reproduction in the rat. Endocrinology 1960, 67:467-483.

21. Hagino N: Influence of hypothyroid state on ovulation in rats. Endocrinology |97|, 88: I332-1336.

22. Telleria CM, Zhong L, Deb S, Srivastava RK, Park KS, Sugino N, ParkSarge O-K, Gibori G: Differential expression of the estrogen receptors $\alpha$ and $\beta$ in the rat corpus luteum of pregnancy: regulation by prolactin and placental lactogens. Endocrinology 1998, 139:2432-2442.

23. Ogle TF, George P: Regulation of the estrogen receptor in the decidua basalis of the pregnant rat. Biol Reprod 1995, 53:65-77.

24. Moore JT, McKee DD, Slentz-Kesler K, Moore LB, Jones SA, Horne EL, Su JL, Kliewer SA, Lehmann JM, Willson TM: Cloning and characterization of human estrogen receptor beta isoforms. Biochem Biophys Res Commun 1998, 247:75-78.

25. Ogawa S, Inoue S, Watanabe T, Hiroi H, Orimo A, Hosoi T, Ouchi Y, Muramatsu M: The complete primary structure of human estrogen receptor $\beta$ (hER $\beta$ ) and its heterodimerisation with ER $\beta$ in vivo and in vitro. Biochem Biophys Res Commun 1998, 243: 122-126.

26. Fuqua SA, Schiff R, Parra I, Friedrichs WE, Su JL, McKee DD, SlentzKesler K, Moore LB, Willson TM, Moore JT: Expression of wildtype estrogen receptor beta and variant isoforms in human breast cancer. Cancer Res 1999, 59:5425-5428.

27. Ogawa S, Inoue S, Watanabe T, Orimo A, Hosoi T, Ouchi Y, Muramatsu M: Molecular cloning and characterization of human estrogen receptor $\beta c x$ : a potential inhibitor of estrogen action in human. Nucleic Acids Res 1998, 26:3505-35I2.

28. Arnold SF, Obourn JD, Yudt MR, Carter TH, Notides AC: In vivo and in vitro phosphorylation of the human estrogen receptor. J Steroid Biochem Mol Biol 1995, 52:159-I7I.

29. Chen D, Washbrook E, Sarwar N, Bates G], Pace PE, Thirunuvakkarasu V, Taylor J, Epstein RJ, Fuller-Pace FV, Egly JM, Coombes RC, Ali $S$ : Phosphorylation of human estrogen receptor alpha at serine 118 by two distinct signal transduction pathways revealed by phosphorylation-specific antisera. Oncogene 2002, 21:492I-493I.

30. Jiang MS, Hart GW: A subpopulation of estrogen receptors are modified by $\mathbf{O}$-linked $\mathbf{N}$-acetylglucosamine. J Biol Chem 1997, 272:242।-2428.

31. Cheng X, Hart GW: Alternative O-glycosylation/O-phosphorylation of serine- 16 in murine estrogen receptor beta: posttranslational regulation of turnover and transactivation activity. J Biol Chem 200I, 276:10570-10575.

32. Zhou Y, Choric LP, Mahesh VB, Ogle TF: Regulation of estrogen receptor protein and messenger ribonucleic acid by estradiol and progesterone in rat uterus. J Steroid Biochem Mol Biol 1993, 46:687-698.

33. Horigome T, Ogata F, Golding TS, Korach KS: Estradiol stimulated proteolytic cleavage of the estrogen receptor in the mouse uterus. Endocrinology 1988, I 23:2540-2548.

34. Loriaux DL, Ruder HJ, Knab DR, Lipsett MB: Estrone sulfate, estrone, estradiol and estriol plasma levels in human pregnancy. J Clin Endocrinol Metab 1972, 35:887-89 .

35. Warne GL, Reyes FI, Faiman C, Winter JSD: Studies on human sexual development. VI concentrations of unconjugated dehydroepiandrosterone, estradiol and estriol in amniotic fluid throughout gestation. J Clin Endocrinol Metab 1978, 47:1363-1367. 
36. Taya K, Greenwald GS: In vivo and in vitro ovarian steroidogenesis in the pregnant rat. Biol Reprod 198I, 25:683-69I.

37. Medlock KL, Lyttle CR, Kelepouris N, Newman ED, Sheehan DM: Estradiol down-regulation of the rat uterine estrogen receptor. Proc Soc Exp Biol Med 1991, 196:293-300.

38. Drummond AE, Baillie AJ, Findlay JK: Ovarian estrogen receptor alpha and beta mRNA expression: impact of development and estrogen. Mol Cell Endocrinol 1999, 149:153-161.

39. Leavitt WW, Cobb AD, Takeda A: Progesterone-modulation of estrogen action: Rapid down-regulation of nuclear acceptor sites for the estrogen receptor. Adv Exp Med Biol 1987, 23:49-78.

40. Sauerwein H, Meyer HHD, Möstl E: Low sensitivity to estrogens in bovine placenta at term. Zentralbl Veterinarmed A 1989, 36:236-240.

4I. Bukovsky A, Caudle MR, Cekanova M, Fernando RI, Wimalasena J, Foster JS, Henley DC, Elder RF: Placental expression of estrogen receptor beta and its hormone binding variant - comparison with estrogen receptor alpha and a role for estrogen receptors in asymmetric devision and differentiation of estrogendependent cells. Reprod Biol Endocrinol 2003, I:36-56.

42. Sheehan DM, Branham WS, Gutierrez-Cernosek R, Cernosek SF Jr: Effects of continuous estradiol administration by polydimethylsiloxane and paraffin implants on serum hormone levels and uterine responses. J Am Coll Toxicol 1984, 3:303-3I6.

43. Hsueh AJW, Peck EJ Jr, Clark JH: Progesterone antagonism of the oestrogen receptor and oestrogen-induced uterine growth. Nature 1975, 254:337-339.

44. Al-Bader MD: Sex steroid hormone action in fetal rat brain: influence of the early intrauterine thyroid hormone environment. In PhD thesis University College London Medical School, Department of Molecular Endocrinology; 1999.

45. Pepe G], Rothchild I: Serum progesterone levels in ovariectomized rats injected with progesterone and estrone: relation to pregnancy maintenance and growth of decidual tissue. Endocrinology 1973, 93:1 193-1199.

46. Butterstein GM, Leathem JH: Placental growth modification during pregnancy in the rat. Endocrinology 1974, 95:645-649.

47. Csapo Al, Csapo EF: Ovariectomy induced placental hypertrophy. Prostaglandins 1973, 4:189-200.

48. Bartholomeusz RK, Bruce NW, Lynch AM: Embryo survival and fetal and placental growth following elevation of maternal estradiol blood concentrations in the rat. Biol Reprod 1999, 6I:46-50.

49. Das SK, Flanders KC, Andrews GK, Dey SK: Expression of transforming growth factor- $\beta$ isoforms $(\beta 2$ and $\beta 3)$ in the mouse uterus: analysis of the perimplantation period and effects of ovarian steroids. Endocrinology 1992, 130:3459-3466.

50. Moulton BC: Transforming growth factor- $\beta$ stimulates endometrial stromal apoptosis in vitro. Endocrinology 1994, 134: 1055-1060.

\section{Publish with Bio Med Central and every scientist can read your work free of charge}

"BioMed Central will be the most significant development for disseminating the results of biomedical research in our lifetime. "

Sir Paul Nurse, Cancer Research UK

Your research papers will be:

- available free of charge to the entire biomedical community

- peer reviewed and published immediately upon acceptance

- cited in PubMed and archived on PubMed Central

- yours - you keep the copyright

Submit your manuscript here:

http://www.biomedcentral.com/info/publishing_adv.asp
BioMedcentral 